\title{
Stakeholders' Information needs, Information Searching and Sharing Behaviour about Rice related Information through Rice Knowledge Management Portal
}

\author{
Sunil Kumar ${ }^{1 *}$, V. Sangeetha ${ }^{1}$, Premlata Singh, R. Roy Burman", \\ Arpan Bhowmik ${ }^{2}$ and Shaik N. Meera ${ }^{3}$
}

${ }^{1}$ Division of Agricultural Extension, ICAR-Indian Agricultural Research Institute, New Delhi, India

${ }^{2}$ ICAR - Indian Agricultural Statistical Research Institute, New Delhi, India

${ }^{3}$ (Agricultural extension), ICAR-Indian Institute of Rice Research, Hyderabad, India

*Corresponding author

\section{Keywords}

Information need, Information need index, Information sharing,

Information searching, Rice farmers, ICT

\section{Article Info}

Accepted: 26 December 2017 Available Online: 10 January 2018

\section{A B S T R A C T}

In this study an attempt was made to analyze the information need of various stakeholders and how Rice Knowledge Management Portal (RKMP) is capable enough in integrating with the information needs in purposively selected Nalgonda and West Godavari districts of Telangana and Andhra Pradesh states respectively. In total, 80 farmers along with 30 scientists and 30 extension personnel were selected as respondents for assessing their information need on rice cultivation and it was measured with modified Standardized Information Need Index (SINI) using ex post facto research design. The study revealed that the information on disease management was perceived most important by majority of farmers (index value $=83$ ) followed by local market price and pest management. Similarly, scientists perceived information on disease management was most important need for them (index value $=83.3$ ) followed by pest management and weather information. In case of extension personnel, information on price and source of input (index value 86.7) perceived highest rank whereas information on disease management and local market price were second and third rank respectively. In the study it was found that plant protection information was searched most by farmers, scientists and extension personnel. Furthermore, it was found that majority of the farmers were sharing information when they meet informally and majority of scientists sharing information when they meet either officially and non-officially, majority of extension personnel shared information when meeting with farmers in their field. The study implied that RKMP played a significant role in meeting the information needs of various stakeholders by providing relevant and timely information on rice cultivation through its various domains. Hence, such knowledge management portals are need of the hour in bridging the information gap/digital divide which exists between lab and land. 


\section{Introduction}

In this era of globalisation agriculture is changing fast. With rapid growth in technology day by day new opportunities has problems are arising for farmers. Agriculture is not only a medium of earning for farmer for sustaining livelihood but also a fast growing area for entrepreneurial activities. More complex technologies are proving lesser implementation by technically weak farmers. There is growing demand for rapid input, service and information delivery among the farmers although, fulfillment of these demands solely by public extension system is limited (Mukherjee et al., 2012). The wide farmer extension workers ratio i.e. 2879:1 (Mukherjee and Maity, 2015), administrative and bureaucratic workload and financial limitations etc. have mode the public extension services more supply driven rather than demand driven (Sulaiman et al., 2005). Hence Knowledge management (KM) is considered to be very difficult task in Indian agriculture and become one of the foremost agendas in many research institutions and organizations (Alavi and Leidner, 2001; Tan and Wong, 2015). Knowledge is reflected as the fourth production aspect after labour, land and capital (AFAAS, 2011). Knowledge and information are the basic element of food security and are indispensable for enabling rural development and bringing socioeconomic changes as well (Munyua, 2000). Oladele (2011) observed that lack of agricultural information is a key factor that has greatly limited agricultural advancement in developing countries. In order to avoid this type of problem, farmers should be in lined with growing technologies to compete and fulfil the information need for various farming activities. Information is an indispensable factor in farming practice and it is the basis of extension delivery (Agbamu, 2006). Information as a critical resource for socioeconomic development enables people to make informed choices towards improving their livelihoods (Matovelo, 2006). Information is an important tool used in the realization of any objective or goal set by individuals and it is a valuable resource required in any society, thus acquiring and using information are critical and important activities (Emmanuel, 2012). Information must be relevant and meaningful to farmers, in addition to being packaged and delivered in a way preferred by them (Diekmann et al., 2009). Keeping in view the significance of ICTs in overall agricultural advancement, it is necessary to promote ICT based agricultural information dissemination to enhance agricultural productivity on one hand and also to provide sustainable agricultural information delivery mechanism (Atibioke et al., 2012). ICT is an emerging tool for achieving meaningful societal transformation (Meera $e t$ al., 2004). Further, the role of ICTs in accessing more information in order to enhance food security and support rural livelihoods has also been increasingly recognised and officially endorsed at the World Summit on the Information Society (IICD, 2007). ICT supports access to timely and relevant information, as well as empower the creation and sharing of knowledge of the farming community itself (Mathur and Goyal, 2014). The goal of Information and Communication Technology (ICT) is to provide the benefits of information revolution to the rural masses by enhancing farming efficiency, farm productivity and farmers' income (Sangeetha et al., 2015). The information usually provided is reported to be focused mainly on policy makers, researchers, students and those who manage policy decisions with little or no attention paid to the information needs of farmers who are the targeted beneficiaries of the policy decisions (Omenesa, 2007). So there is a need to assess the information needs of all the stakeholders of agriculture, so that context-specific information could have higher impacts on the 
adoption of technologies and increase farm productivity for marginal and small agricultural landholders (Sammadar, 2006). The term "information need" that 'a function of extrinsic uncertainty produced by a perceived discrepancy between the individual's current level of certainty about important environmental objects and a criterion state that he seeks to achieve' (Atkin, 1973). Indian agriculture has predominately grown rice and wheat crops and rice is staple crop of India. There are number of sources for information on rice related information, but there is always all the related informations are not readily available. So to solve this problem an attempt was made by Indian rice research institute, Hyderabad to cater the information need of the farmers. So a portal namely, Rice knowledge management portal (RKMP) was developed with eight consortium partners. RKMP serves as an information highway for all rice related information. RKMP provides many specific queries for rice research and cultivation, related to variety selection, disease management, pest and site specific frequently asked questions (Das et al., 2013). The vision is to realise higher productivity and production of rice through improved knowledge and skill sets. The efforts paved the way to reduce the gaps of the growing "digital information divide" specifically in the important cereal crop of the country namely the rice (Meera $e t$ al., 2012). An attempt was made to analyze the information needs, searching and sharing behaviour of stakeholders of RKMP (farmer, scientist and extension personnel) in knowledge management and utilization of information.

\section{Materials and Methods}

The study was conducted in the state of Telangana and Andhra Pradesh. These states were selected purposively for the study location. Since, Indian Institute of Rice Research (IIRR) is the host institute of RKMP and this project is being implemented in these states, rice bowls of India. Multi-stage random sampling technique has been adopted to select the respondents. From each selected state, one district has been selected purposively based on the criteria of RKMP project implementation. Nalgonda district from Telangana and West Godavari district in Andhra Pradesh were selected purposively as the project being implemented in these districts since its inception. For the detailed survey, 10 farmers from each village were selected and thus final sample comprises of 80 farmers from two districts. In case of scientists, 15 respondents were selected for the survey from two selected organizations such as Indian Institute of Rice Research (Hyderabad) and Andhra Pradesh Rice Research Institute and Regional Agricultural Research Station, (APRRI and RARS) Maruteru, West Godavari District, Andhra Pradesh (Acharya N.G. Ranga Agricultural University). Therefore, in total, 30 scientists were selected for the final survey. In case of extension personnel, 15 respondents were selected from each Nalgonda and West Godawari district and thus, 30 in total was selected for the survey. Therefore, the study was conducted among 140 stakeholders of RKMP portal, namely, 80 farmers, 30 scientists, and 30 extension professions. In this study, Information need has been studied for farmers, Scientists and Extension personnel. For assessing Rice related information need, schedules were developed separately. Information related to rice such as input availability, cultural practices, post-harvest practices, market related information and credit related informations were assessed. To assess the information need of respondents, they were asked to give responses on provided list of informations according to their priority. A Likert type scale was used for getting responses on a 5-point scale ranging from very important information to not important information. A score of 5 was given to very important information, 4 against somewhat 
important information so on and so forth. To measure information need of the stakeholders on rice cultivation modified Standardized Information Need Index (SINI) developed by Kabir et al., (2014) was used with following formula.

$\mathrm{INI}=\mathrm{InVI} \times 5+\operatorname{InSI} \times 4+\operatorname{InN} \times 3+\operatorname{InLI} \times$ $2+\mathrm{InNI} \times 1$ Where,

$\mathrm{INI}=$ Information Need Index

InVI = Number of respondents with very important information need

InSI = Number of respondents with somewhat important information need

InN = Number of respondents with neutral information need

InLI= Number of respondents with less important information need

InNI $=$ Number of respondents with not important information need

Standard Information Need index $\left(\right.$ SINI) $=\frac{\text { Computed Information Need Index }}{\text { Possible Highest Information Need Index }} \times 100$

Based on the index value information needs were priorities and highest value was arranged in descending order.

\section{Results and Discussion}

According to Parsad (1992), the information need is a factual situation in which, there exists an inseparable interconnection with 'information' and 'need'. The information originates and is generated because there exist a need or an interest.

The content of information is of primary concern. The basic objectives of studying information needs and use may be:
The explanation of observed phenomena of information use or expressed need;

The prediction of instances of information use and

The control, and thereby improvement of the utilization of information manipulation of essentials conditions

Farmers' needs and information requirements vary by the stages of production in agriculture. In general, all farmers seek to acquire complete, high quality and timely information to make decisions related to their crops, throughout the year. Farmers can reduce the probability and magnitude of losses, if they are able to access relevant and timely information. Evidence suggests that ICT has potential to minimize agriculture production risk due to pest and disease (Mittal, 2012). Farmers need both technical and awareness information corresponding to different farm activities. During the survey, farmers were asked to list the most important information needs related with rice cultivation, which has been listed under 26 major dimensions and ranked based on the standard information need index (SINI) value, using a Likert type scale on a five point continuum of importance from very important to not important. It reveals that information related with disease management has ranked one with SINI value 83.0, whereas information related with local market price (81.25) and pest management (80.5) have scored second and third rank respectively. These information needs were followed by weather information with the value of (79.0), best crop practices (78.5), seed variety (78.0), price and source of the input (77.5), credit (76.7), seed treatment with the value of (75.7), marketing and trade with (76.5), crop insurance (76.2) and fertilizer application (74.5). The least preferred information needs were harvesting (44.7), allied activities (37.7) and natural resource management (35.2).The 
present study has also found that the information related with natural resource management was found to be less important (40.7), similarly harvesting (37.7) and allied activities (36.7) by the farmers (Table 1 ).

Different others studies have been done on the information needs of farmers. The needs were different for different stakeholders according to their position. Burman et al., (2013) in their study reported that most of the farmers needed farm information related to areas such as pest and disease management, improved crop varieties. Saravanan et al., (2009) in their study found that majority of the farmers wanted information on pest and disease management. This is in line with the present study, which found that information need of farmers related with disease management was highest with an index value of 83 followed by information need related with best crop practices (81.25) and weed management (80.5). Kabir et al., (2014) in their study stated that information need related to crop protection, market, climate and credit found to be most needed, while crop production, processing and post-harvest related information found to be less needed information for the farmers. This is in line with the findings of the study by Meitei and Devi (2009) who reported that information related to seed varieties, pesticides and fertilizers were most needed by farmers in rural Manipur. Similarly some author also found the similar result for information needs of the farmers which is mainly information on seeds/input availability (what input to use, how much to use, when and from where to purchase inputs) (Mittal et al., 2013), diseases and pest management(Salau et al., 2013; Shanthasheela et al., 2015), water conservation, post-harvest techniques, irrigation, manure and fertilizer management (Okwu et al., (2009), modern cultivation practices, farmers training programmes, government schemes on agriculture, storage, weather information, sources of farm credit and marketing information (Meera et al., 2004; Tologbonse et al., 2008; and Jalaja et al., 2015).

Researchers in agricultural and biological sciences are interested in analyzing information and data on economic and demographic processes at micro and macro levels. Information needs of the scientists related with rice cultivation, which has again been listed under 26 major dimensions and ranked based on the standard information need index (SINI) value, and responses on different information were collected on five point continuum using Likert type scale. It was found that scientists needed information on disease management, pest management and weather related information, which scored first, second, third rank respectively with the SINI value 83, 81.3 and 80.6 respectively (Table 2). Whereas information related with seed variety (78.0), weed management (79.3), water management (78.6), best crop practices (80.0), soil health (80.0), natural resource management(80.0), crop rotation (80.0), pesticide application (78.6), fertilizer application (78.0), method of planting (77.3), seed treatment (77.3), time to plant (77.3), grading (77.3), machinery (76.0), local market price (74.6), crop insurance (74.0), marketing and trade (70.0), source of input (66.0), Government subsidies (64.0), credit (50.7) were the other important information needs. The least preferred information needs by scientists were harvesting (48.0), storage (44.7) and allied activities 40.7). The result of the study was found in harmony with Singh et al., (2006) and Acheampong et al., (2015).

The backbone of all agricultural extension endeavours is the transfer of agricultural information to enhance the productive capacity of farmers (Umali-Deininger et al., 1994). The extension agents' job was to convince farmers of the potentials of the new 
technology. Communities and the networks to which people belong play a more important role in influencing agricultural practices (Sani et al., 2014). The major duty of agricultural extension workers is the providing of agricultural information to farmers, thereby assisting farmers in increasing their production and they are expected to make research findings available to farmers, who in turn, would bring their problems to the notice of agricultural extension workers for onward transmission to agricultural scientists (Aina, L. O. 1989). Information need of the extension personnel related with rice cultivation which has again been listed under 26 major dimensions and ranked based on the standard information need index (SINI) value, and responses on different information were collected on five point continuum using Likert type scale.. From the table 3 , it is understood that extension personnel wanted information on price and source of input, disease management, local market price, Government subsidies and weather information, which has scored first, second, third, fourth and fifth rank respectively with the SINI value 86.7, 86.0, 85.3, 84.0 and 84.0 respectively. The information related to storing (48.0), marketing and trade (46.6), harvesting (44.6), natural resource management (41.3), machinery (40.6) and allied activities (36.0) were least preferred information by extension personnel.

Extension professional being a connective link between farmers and scientists community have to be more competent so that the information need of the farmers as well as the scientists can be fulfilled. To fulfil all these information needs of the extension professionals should possess exhaustive information about rice and its related information. The similar study was conducted by Aina (1989) in Nigeria and revealed that information needs of the extension workers were in the areas of control of major pests, credit and co-operatives, proper handling of insecticides, marketing system of agricultural products. Study was also found in harmony with Alibeygi et al., (2010).

\section{Information sharing and searching behaviour of farmers}

In this study, an attempt was made to know what kind of information is searched and shared by stakeholders who used RKMP portal

Table 4, revealed that plant protection related information is the most searched information by the farmers. Similarly other information search preferences were rice varieties, weather information and inputs. Least preferred was agronomic practices. Findings of the present investigation are in harmony with the similar study conducted by Babu et al., (2012). Opara (2008) found that farmers were mostly searching information related to marketing, credit facilities, improved crop varieties, agrochemicals, agro- machinery, inputs and implements.

The information search preference of scientists was calculated by using mean rank. It revealed that most of the scientists searched rice varieties (5.83) and plant protection measures (5.10). Next to it was input information (2.93). Whereas least searched information was market (2.77) and weather information (1.33). Information search preference of extension professionals was assessed by calculating mean rank. The information which has highest mean score is the most shared information. According to this, most searched information among the extension professional was input information (5.87) and market information (5.10) plant protection measures followed by (3.30), weather information (3.23). But the least searched information was rice varieties (2.40) Agronomic practices (1.10). 
Table.1 Information needs of farmers in context of rice cultivation $n=80$

\begin{tabular}{|c|c|c|c|c|c|c|c|c|}
\hline \multirow[t]{2}{*}{ S.N. } & \multirow[t]{2}{*}{ Information } & \multicolumn{7}{|c|}{ Information needs based on the Importance } \\
\hline & & VI & SI & $\mathbf{N}$ & LI & NI & INI & SINI \\
\hline 1. & Disease management & 43 & 18 & 10 & 6 & 3 & 332 & 83.0 \\
\hline 2. & Local market price & 38 & 23 & 9 & 6 & 4 & 325 & 81.2 \\
\hline 3. & Pest management & 40 & 19 & 9 & 7 & 5 & 322 & 80.5 \\
\hline 4. & Pesticide application & 36 & 24 & 9 & 7 & 4 & 321 & 80.2 \\
\hline 5. & Weather & 34 & 22 & 13 & 8 & 3 & 316 & 79.0 \\
\hline 6. & Best crop practices & 32 & 22 & 14 & 10 & 4 & 314 & 78.5 \\
\hline 7. & Weed management & 36 & 19 & 10 & 11 & 5 & 313 & 78.2 \\
\hline 8. & Government. Subsidies & 37 & 19 & 10 & 8 & 6 & 313 & 78.2 \\
\hline 9. & Seed variety & 36 & 20 & 10 & 8 & 6 & 312 & 78.0 \\
\hline 10. & Price and source of input & 38 & 10 & 18 & 12 & 2 & 310 & 77.5 \\
\hline 11. & Credit & 32 & 21 & 13 & 10 & 4 & 307 & 76.7 \\
\hline 12. & Marketing and trade & 32 & 23 & 10 & 9 & 6 & 306 & 76.5 \\
\hline 13. & Crop insurance & 32 & 21 & 13 & 8 & 6 & 305 & 76.2 \\
\hline 14. & Seed treatment & 33 & 20 & 11 & 9 & 7 & 303 & 75.7 \\
\hline 15. & Crop rotation & 33 & 18 & 13 & 9 & 7 & 301 & 75.2 \\
\hline 16. & Water management & 31 & 20 & 13 & 9 & 7 & 299 & 74.7 \\
\hline 17. & Fertilizer application & 31 & 20 & 12 & 10 & 7 & 298 & 74.5 \\
\hline 18. & Machinery & 31 & 14 & 15 & 12 & 8 & 288 & 72.0 \\
\hline 19. & Method of planting & 27 & 15 & 18 & 19 & 1 & 288 & 72.0 \\
\hline 20. & Storage & 26 & 15 & 23 & 9 & 4 & 281 & 70.2 \\
\hline 21. & Grading & 7 & 6 & 28 & 15 & 25 & 198 & 49.5 \\
\hline 22. & Soil health & 6 & 8 & 18 & 23 & 25 & 187 & 46.7 \\
\hline 23. & Time to plant & 4 & 7 & 16 & 27 & 26 & 176 & 44.0 \\
\hline 24. & Harvesting & 6 & 6 & 12 & 17 & 39 & 163 & 40.7 \\
\hline 25. & Allied activities & 9 & 4 & 3 & 17 & 47 & 151 & 37.7 \\
\hline 26. & Natural resource management & 4 & 2 & 14 & 11 & 49 & 141 & 35.2 \\
\hline
\end{tabular}

VI=Very Important, SI=Somewhat Important, N=Neutral, LI=Less Important, NI=Not Important. INI= Information Need Index, SINI= Standard Information Need Index 
Table.2 Information needs of the scientists in context of rice $n=30$

\begin{tabular}{|c|c|c|c|c|c|c|c|c|}
\hline \multirow[t]{2}{*}{ S.N. } & \multirow[t]{2}{*}{ Information } & \multicolumn{7}{|c|}{ Information needs based on the Importance } \\
\hline & & VI & SI & $\mathbf{N}$ & LI & NI & INI & SINI \\
\hline 1. & Disease management & 16 & 7 & 4 & 2 & 1 & 125 & 83.3 \\
\hline 2. & Pest management & 16 & 6 & 4 & 2 & 2 & 122 & 81.3 \\
\hline 3. & Weather & 13 & 9 & 5 & 2 & 1 & 121 & 80.6 \\
\hline 4. & Seed variety & 13 & 7 & 5 & 4 & 1 & 117 & 78.0 \\
\hline 5. & Weed management & 14 & 7 & 5 & 2 & 2 & 119 & 79.3 \\
\hline 6. & Water management & 15 & 5 & 5 & 3 & 2 & 118 & 78.6 \\
\hline 7. & Best crop practices & 14 & 6 & 7 & 2 & 1 & 120 & 80.0 \\
\hline 8. & Soil health & 13 & 8 & 6 & 2 & 1 & 120 & 80.0 \\
\hline 9. & Natural resource management & 14 & 8 & 4 & 2 & 2 & 120 & 80.0 \\
\hline 10. & Crop rotation & 13 & 8 & 6 & 2 & 1 & 120 & 80.0 \\
\hline 11. & Pesticide application & 13 & 8 & 5 & 2 & 2 & 118 & 78.6 \\
\hline 12. & Fertilizer application & 13 & 8 & 4 & 3 & 2 & 117 & 78.0 \\
\hline 13. & Method of planting & 15 & 6 & 3 & 2 & 4 & 116 & 77.3 \\
\hline 14. & Seed treatment & 13 & 6 & 6 & 4 & 1 & 116 & 77.3 \\
\hline 15. & Time to plant & 13 & 5 & 8 & 3 & 1 & 116 & 77.3 \\
\hline 16. & Grading & 13 & 7 & 5 & 3 & 2 & 116 & 77.3 \\
\hline 17. & Machinery & 13 & 6 & 5 & 4 & 2 & 114 & 76.0 \\
\hline 18. & Local market price & 14 & 5 & 4 & 3 & 4 & 112 & 74.6 \\
\hline 19. & Crop insurance & 13 & 5 & 5 & 4 & 3 & 111 & 74.0 \\
\hline 20. & Marketing and trade & 12 & 3 & 6 & 6 & 3 & 105 & 70.0 \\
\hline 21. & Source of input & 13 & 2 & 3 & 5 & 7 & 99 & 66.0 \\
\hline 22. & Government subsidies & 10 & 2 & 8 & 4 & 6 & 96 & 64.0 \\
\hline 23. & Credit & 6 & 2 & 4 & 8 & 10 & 76 & 50.7 \\
\hline 24. & Harvesting & 5 & 3 & 2 & 9 & 11 & 72 & 48.0 \\
\hline 25. & Storage & 2 & 2 & 7 & 9 & 10 & 67 & 44.7 \\
\hline 26. & Allied activities & 0 & 4 & 5 & 9 & 12 & 61 & 40.7 \\
\hline
\end{tabular}

$\mathrm{VI}=$ Very Important, SI=Somewhat Important, N=Neutral, LI=Less Important, NI=Not Important. INI= Information Need Index, SINI= Standard Information Need Index 
Int.J.Curr.Microbiol.App.Sci (2018) 7(1): $3001-3015$

Table.3 Information need of extension professionals for rice cultivation $n=30$

\begin{tabular}{|c|c|c|c|c|c|c|c|c|}
\hline \multirow[t]{2}{*}{ S. No } & \multirow[t]{2}{*}{ Information } & \multicolumn{7}{|c|}{ Information needs based on the Importance } \\
\hline & & VI & SI & $\mathbf{N}$ & $\mathbf{L I}$ & NI & INI & SINI \\
\hline 1. & Price and source of input & 19 & 5 & 4 & 1 & 1 & 130 & 86.7 \\
\hline 2. & Disease management & 19 & 5 & 3 & 2 & 1 & 129 & 86.0 \\
\hline 3. & Local market price & 19 & 6 & 2 & 1 & 1 & 128 & 85.3 \\
\hline 4. & Government subsidies & 17 & 6 & 4 & 2 & 1 & 126 & 84.0 \\
\hline 5. & Weather & 16 & 8 & 3 & 2 & 1 & 126 & 84.0 \\
\hline 6. & Pest management & 18 & 5 & 3 & 2 & 2 & 125 & 83.3 \\
\hline 7. & Credit & 16 & 6 & 5 & 2 & 1 & 124 & 82.6 \\
\hline 8. & Seed variety & 16 & 7 & 3 & 2 & 2 & 123 & 82.0 \\
\hline 9. & Soil health & 17 & 5 & 4 & 2 & 2 & 123 & 82.0 \\
\hline 10. & Weed management & 15 & 7 & 3 & 2 & 3 & 119 & 79.3 \\
\hline 11. & Seed treatment & 14 & 6 & 6 & 3 & 1 & 119 & 79.3 \\
\hline 12. & Water management & 15 & 5 & 5 & 3 & 2 & 118 & 78.6 \\
\hline 13. & Best crop practices & 13 & 7 & 5 & 4 & 1 & 117 & 78.0 \\
\hline 14. & Crop rotation & 15 & 5 & 4 & 3 & 3 & 116 & 77.3 \\
\hline 15 & Pesticide application & 13 & 6 & 5 & 4 & 2 & 114 & 76.0 \\
\hline 16. & Crop insurance & 13 & 5 & 5 & 4 & 3 & 111 & 74.0 \\
\hline 17. & Time to plant & 12 & 3 & 6 & 6 & 3 & 105 & 70.0 \\
\hline 18. & Method of planting & 13 & 2 & 3 & 5 & 7 & 99 & 66.0 \\
\hline 19. & Grading & 10 & 2 & 8 & 4 & 6 & 96 & 64.0 \\
\hline 20. & Fertilizer application & 13 & 1 & 2 & 5 & 9 & 94 & 62.6 \\
\hline 21. & Storage & 5 & 3 & 2 & 9 & 11 & 72 & 48.0 \\
\hline 22. & Marketing and trade & 3 & 4 & 5 & 6 & 12 & 70 & 46.6 \\
\hline 23. & Harvesting & 2 & 2 & 7 & 9 & 10 & 67 & 44.6 \\
\hline 24. & Natural resource management & 2 & 2 & 4 & 10 & 12 & 62 & 41.3 \\
\hline 25. & Machinery & 0 & 4 & 5 & 9 & 12 & 61 & 40.6 \\
\hline 26. & Allied activities & 0 & 2 & 5 & 8 & 15 & 54 & 36.0 \\
\hline
\end{tabular}

VI=Very Important, SI=Somewhat Important, N=Neutral, LI=Less Important, NI=Not Important. INI= Information Need Index, SINI= Standard Information Need Index 
Table.4 Information search preference of stakeholders (in context of rice) $n=140$

\begin{tabular}{|c|l|c|c|c|}
\hline \multirow{2}{*}{ S.N. } & Categories of Information & \multicolumn{3}{|c|}{ Mean of ranks of stakeholders } \\
\cline { 3 - 5 } & & Farmers (80) & Scientists (30) & Extension personnel (30) \\
\hline 1. & Plant Protection & 5.950 & 5.10 & 3.30 \\
\hline 2. & Rice Varieties & 5.025 & 5.83 & 2.40 \\
\hline 3. & Market & 3.250 & 2.77 & 5.10 \\
\hline 4. & Weather & 3.063 & 1.33 & 3.23 \\
\hline 5. & Input & 2.538 & 2.93 & 5.87 \\
\hline 6. & Agronomic Practices & 1.175 & 3.03 & 1.10 \\
\hline
\end{tabular}

Table.5 Information sharing pattern of the stakeholders $n=140$

\begin{tabular}{|c|c|c|c|c|c|c|c|}
\hline \multirow[t]{3}{*}{ S.N. } & \multirow{3}{*}{$\begin{array}{l}\text { With whom you are } \\
\text { sharing information }\end{array}$} & \multicolumn{6}{|c|}{ Stakeholders } \\
\hline & & \multicolumn{2}{|c|}{ Farmers (80) } & \multicolumn{2}{|c|}{ Scientists (30) } & \multicolumn{2}{|c|}{ Extension personnel (30) } \\
\hline & & $f$ & $\%$ & $f$ & $\%$ & $f$ & $\%$ \\
\hline 1. & Family members & 11 & 13.75 & 3 & 10.00 & 5 & 16.67 \\
\hline 2. & Friends & 30 & 37.50 & 4 & 13.33 & 3 & 10.00 \\
\hline 3. & Relatives & 09 & 11.25 & 5 & 16.67 & 4 & 13.33 \\
\hline 4. & Fellow farmers/scientists & 13 & 16.25 & 16 & 53.33 & 15 & 50.00 \\
\hline 5. & Neighbours & 17 & 21.25 & 2 & 06.67 & 3 & 10.00 \\
\hline
\end{tabular}

Table.6 Purpose of sharing information of the stakeholders $n=140$

\begin{tabular}{|c|c|c|c|c|c|c|c|}
\hline \multirow[t]{3}{*}{ S.N. } & \multirow{3}{*}{$\begin{array}{l}\text { Purpose of sharing } \\
\text { information }\end{array}$} & \multicolumn{6}{|c|}{ Stakeholders } \\
\hline & & \multicolumn{2}{|c|}{ Farmers (80) } & \multicolumn{2}{|c|}{ Scientists (30) } & \multicolumn{2}{|c|}{ Extension personnel (30) } \\
\hline & & $f$ & $\%$ & $f$ & $\%$ & $f$ & $\%$ \\
\hline 1. & To clear doubt & 26 & 32 & 2 & 06.67 & 6 & 20.00 \\
\hline 2. & To informs others & 33 & 41 & 23 & 76.67 & 16 & 53.33 \\
\hline 3. & To spread the benefits & 21 & 27 & 5 & 16.67 & 8 & 26.67 \\
\hline
\end{tabular}

Table.7 Periodicity of sharing information of the stakeholders $n=140$
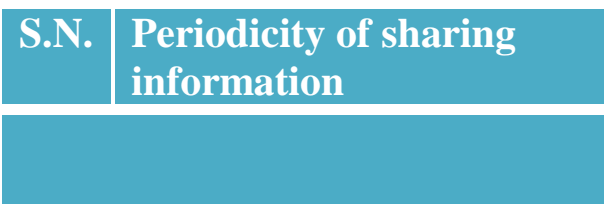

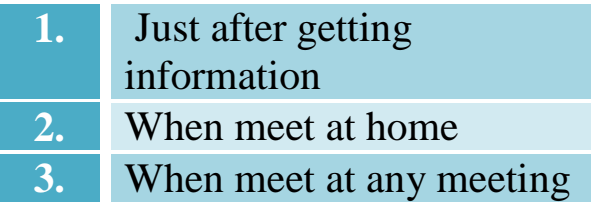

\begin{tabular}{|c|c|c|c|c|c|}
\multicolumn{7}{c|}{ Stakeholders } \\
\hline Farmers (80) & \multicolumn{7}{|c|}{ Scientists (30) } & Extension personnel (30) \\
\hline $\boldsymbol{f}$ & \% & $\boldsymbol{f}$ & $\%$ & $\boldsymbol{f}$ & \% \\
\hline 18 & 22.7 & 6 & 20.00 & 3 & 10.00 \\
\hline 29 & 36 & 8 & 26.67 & 7 & 23.33 \\
\hline 33 & 41.3 & 16 & 53.33 & 20 & 66.67 \\
\hline
\end{tabular}


Table. 8 Type of information shared by the stakeholders $n=140$

\begin{tabular}{|l|l|c|c|c|c|c|c|}
\hline S.N. & $\begin{array}{l}\text { Type of information } \\
\text { shared }\end{array}$ & \multicolumn{8}{|c|}{ Stakeholders } \\
\hline & & \multicolumn{7}{|c|}{ Farmers (80) } & Scientists (30) & Extension personnel (30) \\
\hline & & $\boldsymbol{f}$ & \% & $\boldsymbol{f}$ & \% & f & \% \\
\hline 1. & Plant Protection & 22 & 27.3 & 11 & 36.67 & 10 & 33.33 \\
\hline 2. & Rice Varieties & 13 & 16.0 & 5 & 16.67 & 7 & 23.33 \\
\hline 3. & Market & 09 & 11.7 & 5 & 16.67 & 4 & 13.33 \\
\hline 4. & Weather & 11 & 13.7 & 1 & 03.33 & 2 & 06.67 \\
\hline 5. & Input & 18 & 22.2 & 4 & 13.33 & 3 & 10.00 \\
\hline 6. & Agronomic Practices & 07 & 9.10 & 4 & 13.33 & 4 & 13.33 \\
\hline
\end{tabular}

From Table 5, it was found that the information is mostly shared between friends (37.50\%) followed by neighbours $(21.257 \%)$ and fellow farmers (16.25\%) and least to relatives. The study was supported by Karthikeyan (2008) where the farmers showed similar kind of information sharing behaviour about Kisan Call Centers at Tamil Nadu. A similar study was done by Yadav (2011) in Uttarakhand on agricultural portals and found that that majority of farmers had shared the information with neighbour followed by relatives $(66.26$ per cent each).provided through Agropedia and aAQUA respectively.

Further it was found that 53 per cent scientists were sharing the information with the fellow scientists and farmers whereas 13.3 per cent were shared with relatives. Among the extensional personnel, 50 per cent were sharing the information they got from RKMP portal with fellow farmers, and 16 per cent were shared with family members and similarly with friends and neighbours 10 percent.

Table 6 described the purpose for which information is shared by the farmers. It reveals that most of the RKMP user farmers 41.0 per cent shared information just for the sake of informing others. Whereas 32 per cent farmers shared the information to clear their doubts followed by to spread the benefits what they get because of RKMP 27 per cent. The study was supported by Ansari et al., (2014).

Further in case of scientists it revealed that most of the scientists 76 per cent shared information just for the sake of informing others. Whereas 6 per cent farmers shared the information to clear their doubts followed by to spread the benefits what they get because of RKMP 16 per cent. In case of extension personnel revealed that most of the Extension Personnel 53 per cent shared information just for the sake of informing others. Whereas 20 per cent farmers shared the information to clear their doubts followed by to spread the benefits what they get because of RKMP 26 per cent.

Table 7 showed that most of the RKMP user farmers 41 per cent shared the information whenever they used to meet at their common meeting point followed by whenever they used to meet at home 36 per cent and just after getting the information 22.7 per cent.

It also showed that most of the scientists 53 per cent shared the information whenever they used to meet at their common meeting point followed by whenever they used to meet at office 26 per cent and just after getting the information 20 per cent. Most of the 
extension personnel $(67 \%)$ were sharing the information with the farmers when they meet them at their field followed by when the farmers come to their office $(24 \%)$ and just after getting the information by calling them $(9.3 \%)$

Table 8 depicted the type of information shared related to rice cultivation by the RKMP user farmers. It reveals that most shared information by the farmers was plant protection measures 27.3 per cent. And subsequently input information 22.2, rice varieties $(16 \%)$ and weather information $(13.7 \%)$. It also reveals that least shared information was agronomic practices $(9.1 \%)$. the present study was supported by Diekmann et al., (2009).

It showed that most shared information by scientists was plant protection measures 36.67 per cent Next to it was information related to rice varieties 16.67 per cent. Whereas the least shared information was market 16.67 per cent and weather information 3.33 per cent. Most shared information by extension personnel was plant protection measures (33.3 $\%)$. Next to it was information related to rice varieties $(23.8 \%)$. Whereas the least shared information was weather information $(4.8 \%)$.

Information is a vital and crucial input in agriculture for sustainable agriculture in modern day technologies/ agriculture. Any knowledge management model will lose the sustainability if it has limitations in technology dissemination part. For a successful knowledge management model, information needs, information searching preference of stakeholders needs to be taken care. The ICT based knowledge management models must take into account the importance of information needs of the all the stakeholders, access and utilization of same in order to meet the demand in changing agricultural scenario and for a robust agriculture based economy. For effective dissemination of information, we must ensure that stakeholders should utilize all the available and accessible ICT tools and upgradation in technologies, support of state department of agriculture and extension personnel in effective way.

Tomorrow's society will be more of virtual than physical. Hence, the emerging social media tools need to be integrated well in knowledge management models. Hence information needs, sharing pattern and searching preference of all the stakeholders needs to be taken care while formulating any knowledge management strategies for its effective utilization and necessary redesigning and modification should be adopted. Hence, such knowledge management portals are need of the hour in bridging the information gap/digital divide which exists between lab and land.

\section{References}

Acheampong, L.D. and Dzandu, M., 2015. Information-Seeking Behaviour of Crops Research Scientists in Ghana. In Information and knowledge management, 5(5), 88-93.

AFAAS. 2011. Concept and learning framework for the African Forum for Agricultural Advisory Services (AFAAS). AFAAS, Kampala, Uganda and FARA, Accra, Ghana.

Agbamu J.U., 2006. Essentials of Agricultural Communication in Nigeria. Malthouse Press Limited, Lagos. Pp 34-56.

Aina, L. O. 1989. Information needs of agricultural extension workers in Nigeria.

Alavi M and Leidner DE, 2001. Knowledge management and knowledge management systems: Conceptual foundations and research issues. MIS Quarterly, Vol. 1, pp. 107-36. 
Alibeygi, A.H., Zarafshani, K. and Chizari, M., 2010. Educational and support needs of the agricultural extension agents in Isfahan province, Islamic Republic of Iran. Journal of Agricultural Science and Technology, 2, pp.137-141.

Ansari, M.A. and Sunetha, S., 2014. Agriculture information needs of farm women: A study in State of north India. African Journal of Agricultural Research, 9(19), 1454-1460.

Atibioke, O.A., Ogunlade, I., Abiodun, A.A., Ogundele, B.A., Omodara, M.A. and Ade, A.R., 2012. Effects of Farmers' Demographic Factors on the Adoption of Grain Storage Technologies Developed by Nigerian Stored Products Research Institute (NSPRI): A case study of selected villages in Ilorin West LGA of Kwara State. Research on Humanities and Social Sciences, 2(6), 56-63.

Atkin, C., 1973. Instrumental utilities and information seeking.

Babu, S.C., Glendenning, C.J., AsensoOkyere, K. and Govindarajan, S.K., 2012. Farmers' Information Needs and Search Behaviors. International Food Policy Research Institute, Paper, 1165, pp.1-37.

Burman, R.R., Dubey, S.K., Sharma, J.P., Vijayaragavan, K., Sangeetha, V. and Singh, I., 2013. Information dynamics for designing cyber extension model for agricultural development. Journal of Community Mobilization and Sustainable Development, 8(2), 182185.

Das, D.R., Pandey, P.S., Mishra, A.K. and Meera, S.N., 2013. Rice Knowledge Management Portal for Technology Dissemination: A Case Study for Haryana, Punjab and Uttarakhand States. Indian Journal of Extension Education, 49(1and2), 88-92.
Diekmann, F., Loibl, C. and Batte, M.T., 2009. The economics of agricultural information: factors affecting commercial farmers' information strategies in Ohio. Review of Agricultural Economics, 31(4), 853872.

EMMANUEL H. 2012. Information needs and information seeking behaviour of rural farmers in okpokwu local government area of Benue state of nigeria.

IICD. 2007. How ICT can make a difference in agricultural livelihood. The Common Wealth Ministers Reference Book-2007. http://www.iicd.org/files/ICT\%20and\% 20agricultural\%20livelihoods.pdf.

Jalaja V, Kala PA., 2015. Case study of tribal farmers' agricultural information needs and accessibility in Attappady tribal block, Palakkad. Journal of Humanities and Social Science, 20(8), 7-12.

Kabir, K. H., Roy, D., Sarker, A., Kuri, S. K. 2014. Information Seeking Behavior of the Farmers to Ensure Sustainable Agriculture, Europian Academic Research. 2(3), 3723- 3734.

Karthikeyan. C. 2008. Formative Evaluation of Kisan Call Centers in Tamil Nadull. A Manual. Indian Agricultural Research Institute, New Delhi, Indian in collaboration with Michigan State University, East Lansing, USA. Pp. 87106

Mathur A, Goyal M. 2014. Role of information technology in Indian agriculture. International Journal of Applied Engineering Research. 9(10):1193-8.

Matovelo, D. S., Msuya, J., and DE SMET, E. 2006. Towards developing proactive information acquisition practices among smallholder farmers for empowerment and poverty reduction: a situation analysis. Quarterly bulletin of the International Association of 
Agricultural Information Specialists, 51(3-4), 256-264.

Meera, S.N. Jhamtani, A. and Rao, D.U.M. 2004. Information and communication technology in agricultural development: A comparative analysis of three projects from India. Agricultural Research and Extension Network. Network Paper No. 135, pp.13.

Meitei, Shanta L. and Devi, Purnima Th. 2009. Farmers' information need in rural Manipur: An assessment. Annals of Library and Info. Studies, 56: 35-40.

Mittal, S. 2012. Modern ICT for agricultural development and risk management in smallholder agriculture in India. CIMMYT.

Mittal, S., and Mehar, M. 2013. Agricultural information networks, information needs and risk management strategies: A survey of farmers in Indo-Gangetic Plains of India (Vol. 10). CIMMYT.

Mukherjee, A., and Maity, A. 2015. Publicprivate partnership for convergence of extension services in Indian agriculture. Current Science, 109(9), 1557-1563.

Mukherjee, A., Bahal, R., Roy Burman, R., and Dubey, S. K. 2012. Conceptual convergence of pluralistic extension at Aligarh District of Uttar Pradesh. Journal of Community Mobilization and Sustainable Development, 7(1and2), 8594.

Munyua, H. 2000. Application of ICTs in Africa's agricultural sector: A gender perspective. Gender and the information revolution in Africa, 85124.

Okwu, O. J., and Umoru, B. I. 2009. A study of women farmers agricultural information needs and accessibility: A case study of Apa Local Government Area of Benue State, Nigeria. African Journal of Agricultural Research, 4(12), 1404-1409.

Oladele OI. 2011. Effect of information communication technology on agricultural information access among researchers, extension agents, and farmers in South Western Nigeria. Journal of agricultural and food information, 12(2):167-76.

Omenesa, Z. E. 2007. Assessment of farmers' information needs and other beneficiaries through the NAQAS-ICT. In NAQAS stakeholders meeting on strategies to involve farmers' in NAQAS service in Nigeria held at NAERLS/ABU, Zaria. 8pp.

Opara, U. N. 2008. Agricultural information sources used by farmers in Imo State, Nigeria. Information Development, 24(4), 289-295.

Parsad, H.N. 1992. Information needs and users. Indian Bibliographic Centre, Varanasi. pp. 23.

Salau, E. S., Saingbe, N. D., and Garba, M. N. 2013. Agricultural Information Needs of Small Holder Farmers in Central Agricultural Zone of Nasarawa State. Journal of Agricultural extension, 17(2), 113-121.

Samaddar, A. 2006. Traditional and post traditional: a study of agricultural rituals in relation to technological complexity among rice producers in two zones of west bengal, india. Culture, Agriculture, Food and Environment, 28(2), 108-121.

Sangeetha, V., Burman, R. R., Dubey, S. K., Sharma, J. P., and Singh, I. 2015. Attitude of Agricultural Stakeholders on Use of Short Message Service (SMS) in Transfer of Technology. Indian Journal of Extension Education, 51(1and2), 6065.

Sani, R., Omokore, D., and Achi, N. 2014. Training Needs of Extension Workers: A Case Study of Maigana and Samaru Zones of Kaduna State Agricultural Development Project. Journal of Animal Production Research, 26(1).

Saravanan, R., and Raja, P. 2009. Tayeng 
Sheela; Information input pattern and information need of Tribal Farmers in Arnuchal Pradesh. Indian Journal of Extension Education, 45, 51-54.

Shaik N. Meera, GAK Kumar, PS Pandey, S Arun Kumar and BC Viraktamath 2012. Empowering Farmers through Rice Knowledge Management Portal in India. Agricultural Information and Knowledge for All: Success Stories on ICT/ICM in the Asia-Pacific Region. Asia-Pacific Association of Agricultural Research Institutions (APAARI). FAO Regional Office for Asia and the Pacific. Bangkok.

Shanthasheela, M., and Sindhuja, P. 2015. Information need assessment of farmers for ICT enabled extension. International Journal of Farm Sciences, 5(3), 246-250.

Singh, K. P., and Satija, M. P. 2006. A review of research on information seeking behaviour of agricultural scientists: international perspectives. DESIDOC Journal of Library and Information Technology, 26(2).

Singh, R. K. P., and Singh, K. M. 2012.
Climate Change, Agriculture and ICT: An Exploratory Analysis.

Sulaiman, V., Hall, A., and Suresh, N. 2005. Effectiveness of private sector extension in India and lessons for the new extension policy agenda.

Tan, L. P., and Wong, K. Y. 2015. Linkage between knowledge management and manufacturing performance: a structural equation modeling approach. Journal of knowledge management, 19(4), 814835.

Tologbonse, D., Fashola, O., and Obadiah, M. 2008. Policy issues in meeting rice farmers' agricultural information needs in Niger State. Journal of Agricultural Extension, 12(2).

Umali-Deininger, D., and Schwartz, L. A. 1994. Public and private agricultural extension: Beyond traditional frontiers (Vol. 236). World Bank Publications.

Yadav, K. 2011. Impact assessment of ICTenabled knowledge sharing agri-portals in Uttarakhand (Doctoral dissertation, Govind Ballabh Pant University of Agriculture and Technology).

\section{How to cite this article:}

Sunil Kumar, V. Sangeetha, Premlata Singh, R. Roy Burman, Arpan Bhowmik and Shaik N. Meera. 2018. Stakeholders' Information needs, Information Searching and Sharing Behaviour about Rice related Information through Rice Knowledge Management Portal. Int.J.Curr.Microbiol.App.Sci. 7(01): 3001-3015. doi: https://doi.org/10.20546/ijcmas.2018.701.357 